\title{
Bacterial Contamination of Vacuum-packed Sliced Ham and Sausage
}

(Received December 20, 1979)

\author{
Midori NaKano, Yoko Kubokura and Masuo Ogawa
}

(Tokyo University of Agriculture and Technology: 5-8, Saiwai-cho 3-chome, Fuchu, Tokyo)

\begin{abstract}
Methods of culture for bacteria contained in commercial vacuum-packed sliced ham and sausage were studied, and a survey was conducted to clarify the actual state of bacterial contamination of these meat products. The results obtained can be summarized as follows.

1) Studies on methods of culture: The bacterial count obtained by incubation at $7^{\circ} \mathrm{C}$ was about ten to fifty times higher than that obtained by incubation at $37^{\circ} \mathrm{C}$ up to 3 weeks after packaging. This difference decreased later. There was no significant difference in bacterial count between aerobic and anaerobic culture, regardless of the temperature of incubation. Differences in culture method did not produce large difference in the detected bacterial flora of the meat products, in which Lactobacillus and Streptococcus were predominant. Both genera could also be grown in aerobic culture. Obligate anaerobic bacteria could be grown only in anaerobic culture incubated at $37^{\circ} \mathrm{C}$, but in any case were not predominant.

2) Actual state of bacterial contamination: The highest bacterial count was obtained from aerobic culture on trypicase soy agar medium incubated at $7^{\circ} \mathrm{C}$, among all the methods examined. The count was more than 50,000 per gram in $62.5 \%$, more than $10^{6}$ in $53.0 \%$, more than $10^{7}$ in $40.0 \%$, and more than $10^{8}$ in $9.0 \%$ of the samples taken from vacuum-packed sliced ham and sausage immediately after purchase. The count exceeded $10^{5}$ (on average) within 7 days after packaging. It is urgently necessary to clarify the reason for the bacterial contamination of these meat products from a foodhygienic point of view.
\end{abstract}

\section{Introduction}

Recently the mass production of meat and meat products for distribution and sale in various forms has led to the extensive use of simple plastic film packaging for meat and meat products. ${ }^{1) \sim 15)}$ Vacuum-packed sliced ham and sausage may be regarded as representative cases. The bacteriological quality of these foods, however, has hardly been studied as compared with that of other meats ${ }^{1) \sim 10)}$ and meat product ${ }^{11) \sim 13)}$ packed in vacuo.

The gas permeability of plastic film varies considerably according to the kind of material used. ${ }^{16)-18)}$ Even if the plastic film has a very low permeability, it will be difficult to maintain vacuum-packed sliced ham and sausage under completely anaerobic conditions, judging from the process used in packaging these products. ${ }^{16) \sim 18)}$ On the other hand, it has been reported that in the case of hermetically packed meat products, if not vacuum-packed products, oxygen contained in these products is absorbed by the growth of aerobic bacteria, as well as by the meat itself, and that the partial pressure of carbon dioxide consequently increases. ${ }^{19)}$ Therefore, it is presumed that there may be a difference in predominant microbial flora between packaged and unpackaged meat products.

It is generally known that the microaerobic lactic acid bacterial group is predominant in the microflora of vacuum-packed foods. ${ }^{1), 3), 6) ~}$ 9),11),12),15) This information was obtained 
Table 1. Products Used in the Survey

\begin{tabular}{l|l|c|c|c} 
Brand & Nature of products & $\begin{array}{c}\text { Number of } \\
\text { samples }\end{array}$ & $\begin{array}{c}\text { Days after } \\
\text { vacuum-packaging }\end{array}$ & Remarks \\
\hline I & Chopped ham & 4 & 9 & P, C \\
I & Pressed ham & 4 & 3 & P, C \\
I & Soft salami sausage & 4 & 8 & P, C \\
K & Pork ham & 4 & 7 & C \\
K & Soft salami sausage & 4 & 14 & C \\
N & Pressed ham & 4 & 13 & P, C \\
N & Chopped ham & 4 & 7 & P, C \\
P & Pork ham & 4 & 21 & C \\
P & Bologna sausage & 4 & 16 & C \\
P & Honey ham & 4 & 27 & C \\
P & Luncheon meat sausage & 4 & 13 & P, C \\
S & pressed ham & 4 & 22 & P, C \\
Y & Pressed ham & 4 & 6 & P, C \\
Y & Chopped ham & 4 & 3 & P, C \\
Y & Loin ham & 4 & 103 & C \\
K & Ham, sausage & 4 &
\end{tabular}

$\mathrm{P}$, usage of preservative; $\mathrm{C}$, usage of coloring agent

a) Made in Canada

from experiments with aerobic cultures, however, and little work has been done on anaerobic culture simultaneously with aerobic culture. Accordingly, little is known about the status of obligate anaerobic bacteria in packaged meat products.

Thus, the present investigation was carried out to examine methods of culture of bacteria contained in commercial vacuum-packed sliced ham and sausage, and a survey was conducted to elucidate the actual bacterial contamination of these products.

\section{Materials and Methods}

\section{Materials and their treatment}

The materials used for the survey were 64 samples of 16 brands of vacuum-packed sliced ham and sausage produced in seven plants and purchased from "supermarkets" in the suburban area of Tokyo in the summer of 1975 (Table 1). Most of them had been packaged 1 2 weeks before and some of them more than 150 days before.

Each sample was opened aseptically. A portion was cut off and tested for flavor. The remainder was minced finely and mixed well, then $4 \mathrm{~g}$ was suspended in $36 \mathrm{ml}$ of diluent for anaerobic culture ${ }^{20)}$ and homogenized in a Polytron before culture.

\section{Method of culture}

Before vacuum-packed sliced ham and sausage were examined for bacteriological quality, preliminary experiments were carried out to clarify the effects of the partial pressure of oxygen gas during bacterial culture (aerobic and anaerobic culture), as well as the effects of temperature of incubation $\left(7^{\circ} \mathrm{C}\right.$ for determination of psychrotrophic bacteria and $37^{\circ} \mathrm{C}$ for mesophilic ones), and the type of culture medium.

Aerobic culture was conducted with standard plate agar (SA) and trypticase soy agar (TSA), and anaerobic culture with BL and EG media as recommended by Mitsuoka et $a l .{ }^{20)}$ The surface of each medium was smeared with $0.1 \mathrm{ml}$ of a dilution of the sample sufficient to give a reasonable number of colonies. Four methods of incubation were employed; that is, at $7^{\circ} \mathrm{C}$ for 7 days for aerobic culture, at $7^{\circ} \mathrm{C}$ for 10 days by the steelwool method for anaerobic culture, at $37^{\circ} \mathrm{C}$ for 2 days for aerobic culture, and at $37^{\circ} \mathrm{C}$ for 4 days for anaerobic culture. Colonies were counted and classified, and the various types were separated 
and identified by the methods of Cowan ${ }^{21)}$ and Mitsuoka et al. ${ }^{20)}$ To examine the effect of storage after vacuum-packaging of the meat product upon the results of culture (the number of bacteria and their species), 32 samples (2 samples per brand) were selected, stored for $1 \sim 3$ weeks (or $3 \sim 6$ weeks after packaging), and subjected to the above procedure.

Coliform group bacteria were cultured simultaneously with desoxycholate agar medium for mixed dilution culture at $37^{\circ} \mathrm{C}$ for 1 day.

\section{Results}

Fig. 1 shows the bacterial counts (the geometrical means of the bacterial count per gram) of vacuum-packed sliced ham and sausage (both immediately after purchase and after storage for $1 \sim 3$ weeks) incubated at $7^{\circ} \mathrm{C}$ with various methods of culture and at various times after packaging. There was no significant difference between the results of aerobic culture in SA and TSA media, although the bacterial count tended to be a little higher in TSA than in SA medium. There was no significant difference either in the result of anaerobic culture between $\mathrm{BL}$ and EG media, although the bacterial count tended to be a little higher in $\mathrm{BL}$ than in $\mathrm{EG}$ medium. There was no significant difference in the bacterial count between aerobic and anaerobic culture, although the count was relatively high in aerobic culture on TSA medium at 4 weeks after packaging and in anaerobic culture in $\mathrm{BL}$ medium for the subsequent 2 weeks. It was found that the products were already contaminated with more than $10^{5}$ psychrotrophic bacteria per gram 7 days after packaging.

The number of bacteria grown by each culture method was much smaller after incubation at $37^{\circ} \mathrm{C}$ (Fig. 2) than after incubation at $7^{\circ} \mathrm{C}$ (Fig. 1). At 4 weeks after packaging, the number counted after incubation at $37^{\circ} \mathrm{C}$ was generally ten to fifty times less than

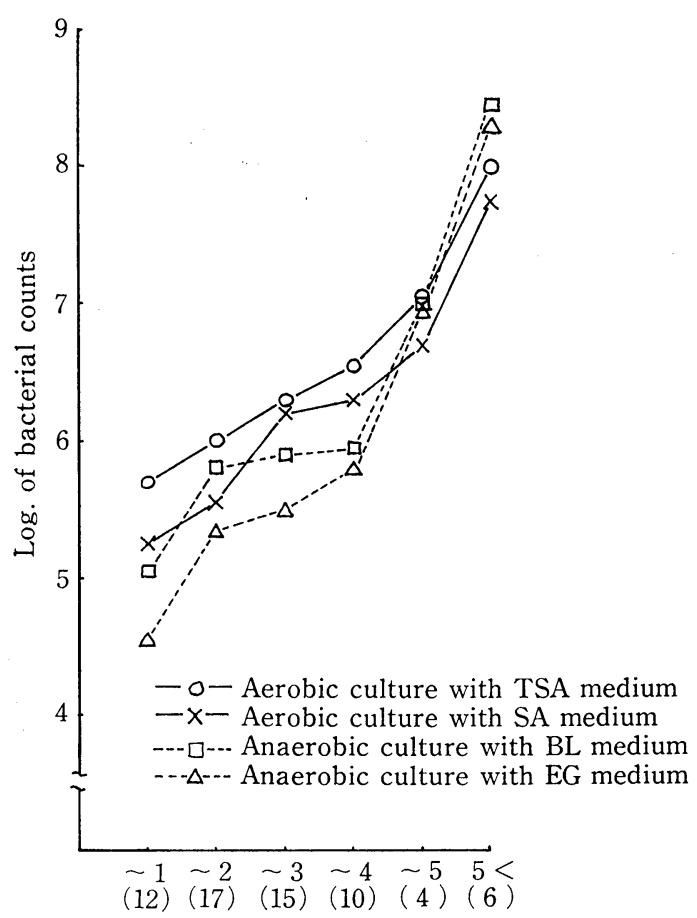

Weeks after vacuum-packaging (values in parentheses are numbers of samples used)

Fig. 1. The bacterial counts of vacuum-packed sliced ham and sausage incubated at $7^{\circ} \mathrm{C}$

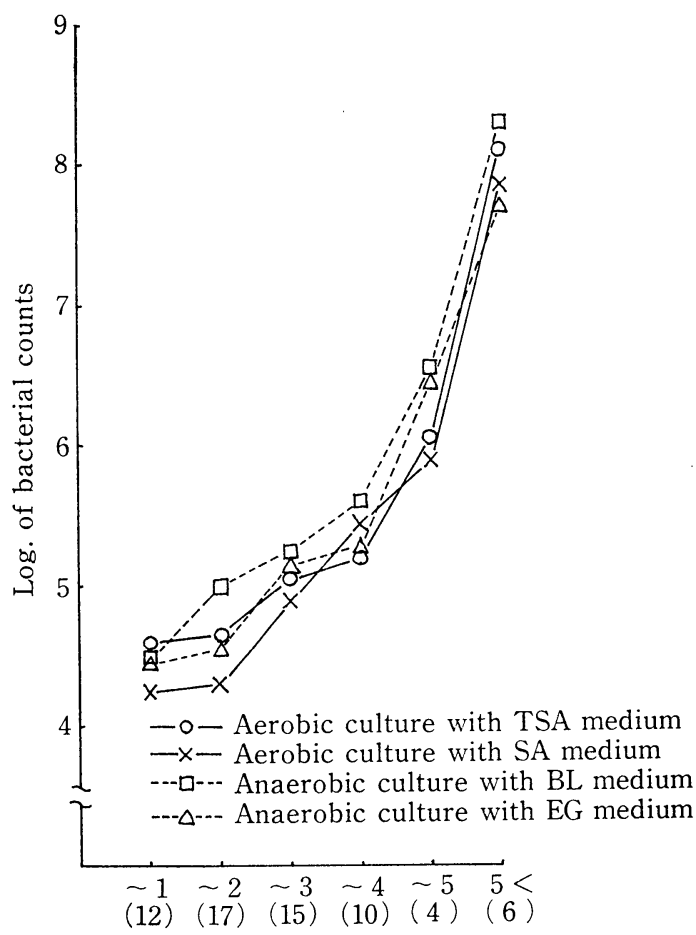

Weeks after vacuum-packaging (numbers in parentheses are numbers of samples used)

Fig. 2. The bacterial counts of vacuum-packed sliced ham and sausage incubated at $37^{\circ} \mathrm{C}$ 
Table 2. The Bacterial Counts of Vacuum-packed Sliced Ham and Sausage Immediately After Purchase

\begin{tabular}{|c|c|c|c|c|c|c|c|c|}
\hline \multirow{2}{*}{$\begin{array}{c}\text { Bacterial } \\
\text { count }\end{array}$} & \multicolumn{3}{|c|}{ Aerobic culture (TSA) } & \multicolumn{4}{|c|}{ Anaerobic culture (BL) } & \multirow{2}{*}{$\begin{array}{l}\text { Coliform } \\
\text { bacteria }\end{array}$} \\
\hline & Incubated at $7^{\circ} \mathrm{C}$ & Incubated & d at $37^{\circ} \mathrm{C}$ & Incubate & ed at $7^{\circ} \mathrm{C}$ & Incubatec & $\mathrm{d}$ at $37^{\circ} \mathrm{C}$ & \\
\hline$<10^{2}$ & $0 \%$ & $16 \%$ & & $9 \%$ & & $3 \%$ & & $88 \%{ }^{\mathrm{c})}$ \\
\hline $10^{2} \sim 10^{3}$ & 37 5a) & 22 & $563^{\text {a) }}$ & 6 & $\left(38^{a}\right)$ & 19 & $500^{\text {a })}$ & 9 \\
\hline $10^{3} \sim 10^{4}$ & 16 & 13 & 50.5 & 22 & 45.0 & 9 & 50.0 & 0 \\
\hline $10^{4} \sim 10^{5}$ & 9 & 3 & & 6 & & 22 & & 3 \\
\hline $10^{5} \sim 10^{6}$ & 9 & 9 & & 13 & & 13 & & 0 \\
\hline $10^{6} \sim 10^{7}$ & 13 & 22 & $\left(77^{\mathrm{b}}\right)$ & 9 & {$[G \Omega b)$} & 13 & $0_{0} 0 \mathrm{~b}$ & 0 \\
\hline $10^{7} \sim 10^{8}$ & 6Z. $5^{\prime \prime}$ & 9 & 43.70 & 16 & $56.2^{\prime \prime \prime}$ & 9 & $50.0^{5}$ & 0 \\
\hline $10^{8}<$ & 9 & 6 & & 19 & & 13 & & 0 \\
\hline
\end{tabular}

a) Per cent of samples with less than 50,000 bacterial counts per gram

b) Per cent of samples with more than 50,000 bacterial counts per gram

c) 85 per cent of these samples contained less than 10 coliform bacteria

that counted after incubation at $7^{\circ} \mathrm{C}$.

Table 2 presents the bacterial counts of vacuum-packed sliced ham and sausage immediately after purchase. These counts were made on TSA medium for aerobic culture, in $\mathrm{BL}$ medium for anaerobic culture, and in DHL medium for coliform bacterial culture. The results of culture by each method are shown in Figs. 1 and 2. The bacterial count was highest in the aerobic culture at $7^{\circ} \mathrm{C}$. In this culture a bacterial count exceeding 50,000 per gram was found in $62.5 \%$ of the samples examined. A bacterial count exceeding a million per gram was found in $53.0 \%$ of these samples. A sour taste was obtained with a product (made in Canada) packaged 107 days before, but nothing abnormal was noted with any other product. Coliform bacteria were detected from 15\% of the samples examined. Their count was less than $10^{2}$ per gram in most of these samples.

Table 3 lists five predominant members of the bacterial flora of vacuum-packed sliced ham and sausage immediately after purchase. These showed a high frequency of appearance [=the ratio of samples from which a given bacterial species was detected $=$ (the number of samples in which this species was detected)/ (the number of samples tested)]. The results in the table are listed according to method of culture and time after packaging. It is of interest that the detection ratios of Lactobacillus and Streptococcus were general- ly high, regardless of the method of culture and the time after packaging. In particular, there was a tendency for the detection ratio of Lactobacillus to increase with time after packaging. When incubation was done at $7^{\circ} \mathrm{C}$, the detection ratio of Lactobacillus was a little higher in anaerobic than in aerobic culture. The Gram-negative rods detected could not be identified, except for a small number which belonged to Pseudomonas and Alcaligenes. There were a few samples from which obligate anaerobic bacteria were detected by anaerobic culture incubated at $7^{\circ} \mathrm{C}$. A small number of obligate anaerobic bacteria were detected in about $20 \%$ of the samples examined by anaerobic culture at $37^{\circ} \mathrm{C}$, regardless of the time after packaging.

\section{Discussion}

Suitable methods for the culture of bacteria contained in vacuum-packed sliced ham and sausage were studied. It was found that the partial pressure of oxygen gas at the time of culture had little effect upon the number of bacteria grown on the medium. When the bacterial flora of each sample was examined, Lactobacillus and Streptococcus, which could grow even in aerobic culture, were predominant in both aerobic and anaerobic culture, showing no marked difference in growth between the two methods of culture. Therefore, it appears that groups of anaerobic bacteria are unlikely to be overwhelmingly predominant 
Table 3. The Five Predominant Members of the Bacterial Flora of Vacuum-packed Sliced Ham and Sausage Immediately After Purchase

\begin{tabular}{|c|c|c|c|c|}
\hline \multirow{2}{*}{$\begin{array}{c}\text { Weeks after } \\
\text { vacuum-packaging }\end{array}$} & \multicolumn{2}{|c|}{ Aerobic culture (TSA) } & \multicolumn{2}{|c|}{ Anaerobic culture (BL) } \\
\hline & Incubated at $7^{\circ} \mathrm{C}$ & Incubated at $37^{\circ} \mathrm{C}$ & Incubated at $7^{\circ} \mathrm{C}$ & Incubated at $37^{\circ} \mathrm{C}$ \\
\hline $0 \sim 1$ & $\begin{array}{l}\text { Streptococcus } \\
\text { Lactobacillus } \\
\text { Micrococcus } \\
\mathrm{G} \oplus \mathrm{R} \\
\mathrm{G} \oplus \mathrm{R}\end{array}$ & $\begin{array}{l}\text { Lactobacillus } \\
\text { Streptococcus } \\
\mathrm{G} \oplus \mathrm{R} \\
\mathrm{G} \oplus \mathrm{R} \\
\mathrm{G} \oplus \mathrm{C}\end{array}$ & $\begin{array}{l}\text { Streptococcus } \\
\text { Lactobacillus } \\
\mathrm{G} \oplus \mathrm{R} \\
\text { Enterobacteriaceae } \\
\mathrm{G} \oplus \mathrm{R}\end{array}$ & $\begin{array}{l}\text { Streptococcus } \\
\mathrm{G} \oplus \mathrm{R} \\
\mathrm{G} \oplus \mathrm{R} \\
\text { Lactobacillus } \\
\text { Anaerobe }\end{array}$ \\
\hline$\sim 2$ & $\begin{array}{l}\mathrm{G} \oplus \mathrm{R} \\
\text { Streptococcus } \\
\text { Lactobacillus } \\
\text { Micrococcus } \\
\text { Alcaligenes }\end{array}$ & $\begin{array}{l}\text { Lactobacillus } \\
\mathrm{G} \oplus \mathrm{R} \\
\text { Streptococcus } \\
\mathrm{G} \oplus \mathrm{R} \\
\mathrm{G} \oplus \mathrm{C}\end{array}$ & $\begin{array}{l}\mathrm{G} \oplus \mathrm{R} \\
\text { Streptococcus } \\
\text { Lactobacillus } \\
\mathrm{G} \oplus \mathrm{C} \\
\mathrm{G} \oplus \mathrm{R}\end{array}$ & $\begin{array}{l}\text { Streptococcus } \\
\mathrm{G} \oplus \mathrm{R} \\
\text { Lactobacillus } \\
\mathrm{G} \oplus \mathrm{C} \\
\text { Anaerobe }\end{array}$ \\
\hline $2<$ & $\begin{array}{l}\text { Lactobacillus } \\
\mathrm{G} \oplus \mathrm{R} \\
\mathrm{G} \oplus \mathrm{R} \\
\text { Pseudomonas } \\
\text { Yeast }\end{array}$ & $\begin{array}{l}\text { Lactobacillus } \\
\mathrm{G} \oplus \mathrm{R} \\
\mathrm{G} \oplus \mathrm{R} \\
\text { Streptococcus } \\
\mathrm{G} \oplus \mathrm{C}\end{array}$ & $\begin{array}{l}\text { Lactobacillus } \\
\mathrm{G} \oplus \mathrm{R} \\
\mathrm{G} \oplus \mathrm{R} \\
\text { Streptococcus } \\
\text { Actinomycetes }\end{array}$ & $\begin{array}{l}\text { Lactobacillus } \\
\mathrm{G} \oplus \mathrm{C} \\
\text { Streptococcus } \\
\mathrm{G} \oplus \mathrm{R} \\
\text { Anaerobe }\end{array}$ \\
\hline
\end{tabular}

These bacteria are listed in decreasing order of frequency of appearance.

$\mathrm{G} \ominus \mathrm{R}$ : Gram-negative rods which could not be identified

$\mathrm{G} \oplus \mathrm{R}$ : Gram-positive, catalase positive, asporogenous rods

$\mathrm{G} \oplus \mathrm{C}$ : Gram-positive cocci which could not be identified

in the bacterial flora of sliced ham and sausage packed in plastic film. When anaerobic culture was carried out at $37^{\circ} \mathrm{C}$, small numbers of obligate anaerobes were detected in samples at all times after packaging. When anaerobic culture was performed at $7^{\circ} \mathrm{C}$, the counts of anaerobic bacteria tended to increase gradually with time after packaging. These results suggest that anaerobic culture may be required under some circumstances for the bacteriological quality evaluation of vacuum-packed sliced ham and sausage. Motegi ${ }^{17)}$ conducted experimental studies on vcuum-packed fish sausage and suggested that anaerobic culture was necessary for the evaluation of this food. When the product was examined within 3 weeks after packaging, the counts of bacteria grown after incubation at $7^{\circ} \mathrm{C}$ were about ten to fifty times higher than those after incubation at $37^{\circ} \mathrm{C}$. The difference decreased gradually with the lapse of time and was almost absent at 6 weeks. These results are different from those obtained by the author ${ }^{22)}$ for milk supplied to the market by the coldchain system. In the case of milk in cold storage, the ratio of the count after incubation at $7^{\circ} \mathrm{C}$ to that after incubation at $37^{\circ} \mathrm{C}$ increased gradually with time of storage. In this case, Pseudomonas was usually overwhelmingly predominant in the bacterial flora of the milk. Accordingly, the difference in bacterial counts of food between cultures incubated at different temperatures may vary not only with the temperature of storage of the food but also with the nature of the food and the mode of packaging. ${ }^{1)}$

At present there are no legal standards for bacterial counts tolerable for ham and sausage in Japan. If the existing standard bacterial count tolerable for fresh milk (less than 50,000 per milliliter) is used for the evaluation of these meat products, $62.5 \%$ of the samples examined showed a count exceeding this value (in the case of aerobic culture at $7^{\circ} \mathrm{C}$ ). In general, food begins to deteriorate when its bacterial count exceeds $10^{7}$. If this is regarded 
as a standard, $40 \%$ of the samples showed a count exceeding $10^{7}$. However, even meat products presenting a high bacterial count of $10^{7}$ or more tasted acceptable, except for products made in Canada which tasted sour. The reasons why the meat products were contaminated with such high levels of bacteria immediately after purchase may be as follows. (1) Before being sliced, the original ham may have been contaminated with bacteria through a breakage, such as a pinhole, in the container. (2) Recontamination may have occurred in the processes of slicing and packaging ${ }^{14)}$. (3) The temperature of storage may have been inappropriate for the packaged products. Recently, the authors have encountered some samples contaminated for the first of these reasons.

Hashimoto et $a l .^{23)}$ conducted a survey on bacterial contamination, collecting samples of unpackaged sliced ham sold in meat shops in the urban area of Fukuyama, Hiroshima Prefecture. The total and psychrotrophic bacterial counts were less than $10^{6}$ per gram in most of the samples collected. This result can be interpreted as indicating that ham was sliced in these shops themselves, and that the sliced product was sold within a day or two.

According to Hashimoto et al. ${ }^{23)}$ unpackaged sliced ham was contaminated mainly with Gram-negative rods such as Acinetobacter, Aeromonas, Alcaligenes, Enterobacter, and Pseudomonas, and no lactic acid bacteria were detected. In contrast, vacuum-packed sliced ham and sausage were contaminated overwhelmingly with lactic acid bacteria such as Lactobacillus and Streptococcus and to some degree with Pseudomonas. This result suggests that the lactic acid bacterial group has a strong affinity for meat, and that changes in internal gas partial pressure caused by vacuum packaging stimulated the activity of the microaerobic lactic acid bacterial group and inhibited that of the strongly aerobic Pseudomonas and other bacterial groups. ${ }^{7)}{ }^{10)}$ The lactic-acid bacterial group may thus have become predominant and inhibited the growth of Pseudomonas and other bacterial groups in packaged sliced ham and sausage. ${ }^{8), 15)}$ Clearly, further studies should be made on the food-hygienic significance of lactic-acid bacteria in these meat products.

\section{References}

1) Adams, J. R., Huffman, D. L.: J. Food Sci. 37, 869 872 (1972).

2) Bailey, J.S., Reagan, J. O., Carpenter, J. A., Schuler, G. A.: ibid., 44, 134 137 (1979).

3) Beebe, S. D., Vanderzant, C., Hanna, M.O., Carpenter, Z. L., Smith, G.C.: J. Mill \& Food Technol. 39, 600 605 (1976).

4) Sutherland, J.P., Patterson, J.T., Murray, J. G.: J. Appl. Bact. 39, 227 237 (1975).

5) Patterson, J.T., Gibbs, P. A.: ibid., 43, 25 38 (1977).

6) Seideman, S.C., Vanderzant, C., Hanna, M. O., Carpenter, Z. L., Smith, G. C.: J. Milk \& Food Technol. 39, 745 753 (1976).

7) Christopher, F.M., Vanderzant, C., Carpenter, Z. L., Smith, G. C.: J. Food Protection, 42, 323 327 (1979).

8) Newton, K. G., Gill, C. O.: J. Appl. Bact. 44, 91 95 (1978).

9) Ozawa, S., Kosaka, K., Yano, S., Shimizu, U., Kaneko, E.: Jap. J. Zootech. Sci., 45, $327 \sim 333$ (1974).

10) Christopher, F.M., Seideman, S.C., Carpenter, Z. L., Smith, G. C., Vanderzant, C.: J. Food Protection 42, 240 244 (1979).

11) Kempton, A.G., Bobier, S. R.: Can. J. Microbiol., 16, 287 297 (1970).

12) Shaw, B. G., Harding, C. D.: J. Appl. Bact., 45, 39 47 (1978).

13) Tonge, R. J., Baird-Parker, A.C., Cavett, J. J.: ibid., 27, 252 264 (1964).

14) Mol, J.H.H., Hietbrink, J.E.A., Mollen, H. W. M., Tinteren, J. V.: ibid., 34, 377 397 (1971).

15) Stiles, M.E., Ng, L. K.: J. Food Protection, 42, 464 469 (1979).

16) Nalleck, F.E., Ball, C. O., Stier, E.F.: Food Tech., 12, 301 307 (1958).

17) Motegi, S.: Bull. Jpn. Soc, Sci, Fish., 44, 477 483 (1978).

18) Ueno, S.: J. Food Hyg. Soc. Japan, 3, 220 238 (1962).

19) Gardner, G. A., Carson, A. W., Patton, J.: J. Appl. Bact., 30, 321 333 (1967).

20) Mitsuoka, T., Sega, T., Yamamoto, S.: Zbl. Bakt. I. Abt. Orig. 195, 455 469 (1965).

21) Cowan S. T.: "Manual for the identification of medical bacteria, 2nd ed." (1974), Cambridge University Press, England.

22) Ogawa, M.: Bull. of the Faculty of Agriculture, Tokyo University of Agriculture and Technology, 11, 1 88 (1968).

23) Hashimoto, H., Murakami, Y., Ohta, Y.: J. Food Hyg. Soc. Japan, 14, 167 172 (1973). 